C 107

\title{
水を封入したアルミニウム容器内の衝撃波挙動について
}

\author{
佐々木 俊昭 ${ }^{\circ}$ (神戸大院), 阿部 晃久 (神戸大院)，三村 治夫(神戸大)
}

\section{Study on Behavior of Shock Waves in Sealed Aluminum Containers with Water}

Toshiaki Sasaki, Akihisa Abe and Haruo Mimura

\begin{abstract}
This paper reports the study on behavior phenomenon of shock waves in water sealed with an aluminum container numerically and experimentally. In the numerical study, the propagation of shock waves in the container is calculated by LS-DYNA using the Johnson-Cook model and the Tait equation. We observe the propagation phenomena of shock waves generated in water part of the container by elastic-plastic deformation of aluminum using the schlieren method. From these results, we examine the complicated propagation of shock waves in the target container.
\end{abstract}

Keywords: Shock waves, Aluminum container, Schlieren method, Numerical simulation

\section{1. 緒 論}

近年，船舶における各港湾間でのバラスト排水におい て有害な微生物の移動による海洋生態系破壊問題が，「海 の環境保全」に関する解決す心゙き大きな課題となってい $る^{(1)}$. 現在，著者らは新しいバラスト水殺菌処理技術開 発のため,バラスト水に含まれる海洋細菌に衝撃圧力を 与え，それらの耐衝搫性について研究を行っている，海 洋生物に作用させる衝撃圧力は，一段式ガス銃で加速さ れた飛翔体を海洋細菌浮遊液を封入したアルミニウム容 器に衝突させ，発生させる．本方法により，容器内に数 百 MPa レベルの衝撃圧力を発生させることができ, 安定 した試料海水の回収が可能である. 本実験における菌体 浮遊液中の不活性効果については，第一波衝撃波による 急峻な正の圧力変動やその背後に現れる負圧力が密接に 関係していると考えられているが，細菌の不活性化メ力 ニズム等末だ明らかにされていない(2). 本研究では, 容 器内に生じる複雑な衝撃波挙動についてより詳細に理解 するため, LS-DYNA による数值シミュレーション，お よび, シュリーレン法による可視化実験を試みる.

\section{2. 実 験}

容器内の試料液中に衝撃波を発生させるため一段式ガ ス銃（トライエンジニアリング社製）を使用した。ガス 銃の口径は $40 \mathrm{~mm}$ ，砲身長は $2 \mathrm{~m}$ である，飛翔体は，直 径 $40 \mathrm{~mm}$, 長さ $40 \mathrm{~mm}$ で $\mathrm{ABS}$ 樹脂材料から作製した。 可視化実験のための標的容器は，2枚のアクリル板

$(40 \mathrm{~mm} \times 40 \mathrm{~mm} \times 5 \mathrm{~mm})$ と $40 \mathrm{~mm} \times 40 \mathrm{~mm}$ の板の中央 を長方形（綐 $15 \mathrm{~mm} \times$ 横 $20 \mathrm{~mm}$ ）にくり抜かれた厚さ $5 \mathrm{~mm}$ のアルミニウム板一枚を用いて作製した. 封入水量 は $1.4 \mathrm{ml}$ である．飛翔体前面に直径 $38 \mathrm{~mm}$ ，厚さ $1 \mathrm{~mm}$ のアルミニウム板を貼り付け, 標的容器に衝突させるこ とにより水中に衝撃波を発生させる. 可視化方法はシュ リーレン法を用いた．可視化光源には，ナノパルスライ ト及びランプハウス（惏菅原研究所, NP-2, NPL-18）, 発光遅延装置としてパルスジェネレー夕(俳菅原研究所, FG-310)を使用した，光学系は 4 枚の光学レンズ，ピン ホール，ナイフェッジから構成され，カメラは最大有効 画素 12.4 メガピクセルのレンズ交換式一眼レフレック スタイプデジタルカメラ（Nikon，D2x）を使用した。 可視化光源のトリガは, 標的容器の衝突面にピンセンサ 一を配置して行った。 


\section{3. 数値計算}

数值計算は, 固体と液体中に生じる動的挙動を同時に 扱える汎用非線形動的構造ソフト LS-DYNA（(株) CRC ソリューションズ) を用いて行った. アルミニウム材料 に対して Johnson-Cook 弹塑性モデル(3)を用いた。 Johnson·Cook 弹塑性モデルは次式で与えられる.

$$
\sigma_{y}=\left(\mathrm{A}+\mathrm{B} \overline{\varepsilon_{p}{ }^{\mathrm{n}}}\right)\left(1+\mathrm{C} \ln \varepsilon^{*}\right)\left(1-T^{\star_{\mathrm{m}}}\right)
$$

式中の記号は以下の通りである.

$\sigma_{y} \quad:$ 相当降伏応力

$\mathrm{A}, \mathrm{B}, \mathrm{C}, \mathrm{n}, \mathrm{m}$ : 材料定数

$\overline{\varepsilon_{p}} \quad:$ 相当塑性ひずみ

$\dot{\varepsilon}=\overline{\varepsilon_{p}} / \varepsilon_{0}: \varepsilon_{0}=1 \mathrm{~s}^{-1}$ に対する無次元相当塑性ひずみ速度 $T^{*}=\left(T-T_{\text {room }}\right) /\left(T_{\text {melt }}-T_{\text {room }}\right) \quad:$ 無次元温度

一方, 水の状態方程式は以下に示す Tait 式を用いた.

$$
P=\alpha\left[\left(\frac{\rho}{\rho_{0}}\right)^{\beta}-1\right]
$$

$P$ はゲージ圧力, $\rho$ は密度, $\alpha, \beta$ は定数である.

\section{4. 結果と考察}

図 1 に海洋細菌の不活性効果の調查実験で使用した容 器内の波動現象の計算結果を示す. 図は円柱型容器の対 称軸から上半分の断面に対する圧力分布を示している.

図 1 は, 衝突面(左端)から発生したアルミニウム中の衝 撃波が,封入された水部周りを回折し, 対称軸上で反射し た時刻の圧力分布図である. アルミニウム材料中の衝撃 波伝播速度は, 海水より約 3 倍早いためアルミニウム中 の衝撃波が先行する.一方, 海水中の衝撃波はほぼ平面を 保ち, 水部中央辺りに達している.

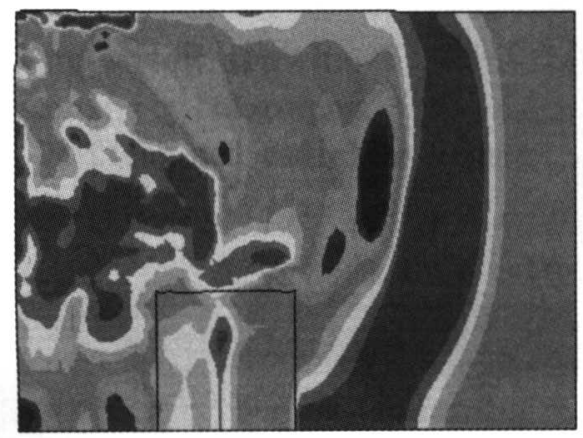

Fringe Levels $1.500 \mathrm{e}+02$ $1.200 \theta+02$ $9.000 \theta+01$ $6.000 \theta+01$ $3.000 e^{+01}$ $0.000 e+00$ $-3.000 e+01$ $-6.000 \mathrm{e}+01$ $-9.000 e+01$ $-1.200 \mathrm{e}+02$ $-1.5000+02$

Fig.1 Computational pressure contours in a target container.
図 2 にシュリーレン法を用いて撮影した標的容器中央 部での可視化写真を示す．写真の左側面で発生した衝撃 波は, 右方向に進行する. 水の圧縮率が低いため, シュ リーレン像は非常に不鮮明である.

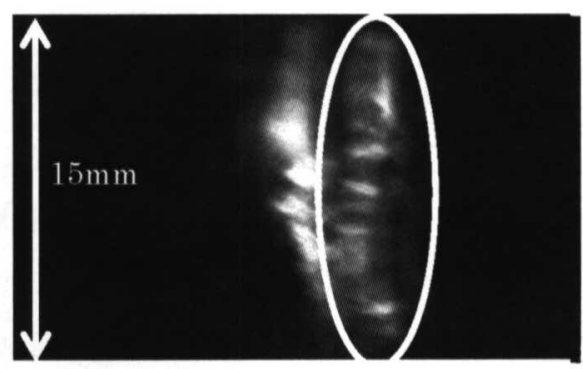

Fig.2 A schlieren photograph of a shock wave in the target container

図 1 のシミュレーション結果から対称軸に沿う方向の 圧力変化は, 衝撃波面背後の圧縮状態から波面一向かっ て圧力が上昇し, 波面前方で圧力が減少することが示さ れている，密度においても同様の変化が生じていると考 えられることから,シュリーレン写真上では, 水中衝撃波 進行方向に明から暗の光の変化が記録されると考えられ る. 以上より, 図 2 中の白丸内が衝撃波面の像であると 推測した.

\section{5. まとめ}

本研究では, アルミニウム容器に封入された水中に生 じる衝撃波伝播現象について LS-DYNA による数值計算 とシュリーレン法による可視化計測を試みた．数值シミ ユレーションから容器内の詳細な波動現象を得る事が出 来た. 今後, 数值計算結果と比較可能な可視化データの 収集を行い，容器内の衝撃波挙動について検討を行う予 定である.

\section{謝 辞}

本研究の一部は, 日本学術振興会科学研究補助金 (基盤 C-18560768）から支援を受けた。ここに付記し心より謝 意を表す。

\section{参考文献}

（1）石田廣史 (研究代表者), “船舶バラスト排水が及ぼ す海洋環境影響とその処理技術の開発に関する研 究”, 研究成果報告書, (2004)

（2）河㠃英樹, “海洋ビブリオ属細菌の衝撃殺菌にお ける圧力波形効果”, 神戸大学修士学位論文，(2006)

(3) W. K. Rule, et al, "A revised form the JohnsonCook strength model”, (1998), pp.609-624 